\title{
The Role of Occupational Health and Safety in the Relationship between Psychological Empowerment and Career Satisfaction
}

\author{
Ömer TURUNÇ iD a İrfan AKKOÇ iD b Abdullah ÇALIŞKAN iD c \\ a Antalya Bilim University, Business Administration, Antalya, Turkey, omer.turunc@antalya.edu.tr \\ b Toros University, Mersin, Turkey. dr.akkoc@gmail.com \\ c Toros University Health Administration, Toros University, Mersin, Turkey. abdullah.caliskan@toros.edu.tr
}

\begin{tabular}{|c|c|}
\hline ARTICLE INFO & ABSTRACT \\
\hline $\begin{array}{l}\text { Keywords: } \\
\text { Psychological Empowerment } \\
\text { Career satisfaction } \\
\text { Occupational health and } \\
\text { safety } \\
\text { Work safety } \\
\text { Public health institutions }\end{array}$ & $\begin{array}{l}\text { Purpose - Nowadays, career satisfaction is one of the worker's expectations and the worker's } \\
\text { efficiency inputs. Removing the obstacles in front of career satisfaction is one of the critical success } \\
\text { factors in the business. Also, psychological empowerment is one of the ways of increasing career } \\
\text { satisfaction. There are a lot of factors in the relationship between psychological empowerment - } \\
\text { career satisfaction. It is thought that the work safety is one of them. The present study aims to } \\
\text { investigate (1) the direct effects of psychological empowerment on career satisfaction and (2) the } \\
\text { moderating role of work safety in the relationship between psychological empowerment and career } \\
\text { satisfaction using a public health sector sample. } \\
\text { Design/methodology/approach - Theory-based hypotheses are tested with a sample of } 420 \text { obtained } \\
\text { in } 2019 \text { from workers from the public health sector, Antalya/Turkey by using SPSS and AMOS. } \\
\text { Findings - The results demonstrated that the moderator effect of work safety perception in the effect } \\
\text { of psychological empowerment and its dimensions on career satisfaction exists except for the } \\
\text { relationship between perceived control and career satisfaction. That is, work safety perception } \\
\text { moderates the effect of psychological empowerment on the career satisfaction of workers. } \\
\text { Discussion - The findings have shown that when work safety perception is low, the effect of } \\
\text { psychological empowerment on career satisfaction is high in a positive direction. Although this } \\
\text { finding is unexpected, in some studies it matches up to the findings. Whereas the existence of work } \\
\text { safety in the working environment may cause the effects of other variables to be ignored for career } \\
\text { satisfaction, it is thought that behaviors aimed at empowering workers may be perceived more } \\
\text { positively by workers. And it can be a motivation tool causing them to be able to ignore many } \\
\text { negative conditions in cases when work safety perception is low. Within this context, this finding is } \\
\text { unexpected but it can be considered positively. }\end{array}$ \\
\hline
\end{tabular}

\section{Introduction}

Violent competitive environment arising with the increasing suppression of globalization has increased the quality of service given to customers in organizations and the subject of empowerment of workers providing this service has come to the fore since the second half of the 1980s. In addition, personnel empowerment thought that workers will have positive effects on their organizational behaviors in the workplace, faces us as a term attracting attention in different areas especially in human resources and management. Personnel empowerment is defined as the transfer of authority and transfer of decision process to lower-level workers (Conger and Kanungo, 1988:473). An empowered worker gains more qualifications in reaching the goals of an organization and becomes proactive (Robbins, 2003:479). So, it has positive effects on both worker and organizational results. It is thought that an important output that will have positive effects on workers is career satisfaction. This variable of career satisfaction, which is defined as the perception of workers about career success (Judge et al., 1999) has attracted the attention of researchers and practitioners in recent years. According to social cognition, behaviors of people depend more on the perception of reality than on reality itself (Bandura, 2001). Therefore, when career success is compared with objective criteria, career satisfaction is much more important in estimating attitudes and behaviors of workers, even organizational results. Career satisfaction is an important subject in the research of career because the perception of subjective performance is seen to be about many work behaviors and well-being. (Abele and Spurk, 2009; Ng et al., 2005; Spurk et al.,

\section{$\underline{\text { Suggested Citation }}$}

Turunç, Ö., Akkoç, İ., Çalışkan, A. (2020). The Role of Occupational Health and Safety in the Relationship between Psychological Empowerment and Career Satisfaction, Journal of Business Research-Turk, 12 (3), 2864-2878. 


\section{Ö. Turunç - İ. Akkoç - A. Çalışkan 12/3 (2020) 2864-2878}

2011:315). The probability of leaving of employment of workers with career satisfaction is less. So, such type of organizations makes the most valuable investment which is to be made in human resources and have vital advantages against their global opponents.

The moderator variable which is thought it will have an effect on the relation between psychological empowerment and career satisfaction at the critical level has been determined as workplace safety because health and safety have been one of the most important basic concepts in all stages of civilization. It is a leading and determinative and strategic concept in all areas of human life. Naturally, it faces us as an output of the function of management which is given importance most and which is given a place in the operation of the organization and the worker relations in terms of both organizations and workers in work life. Otherwise, it faces us as a variable that shakes the foundation of functions of management and which can create a devastating effect in the operation of an organization. These devastating effects are in the research of the International Labor Organization (ILO). According to data obtained from these studies, it is thought that 2.34 million workers die every year because of occupational diseases or accidents. 317 million workers catch diseases related to work and about 337 million fatal or nonfatal work accidents happen a year. Economically, it is estimated that $4 \%$ of GDP in the world is lost as a result of occupational diseases and accidents (ILO).

Organizational and industrial psychology, work psychology, industry relations, and industry sociology are scientific areas that help understand the structure and operation of organizations and reasons for work diseases and injuries at the workplace. It is seen that the number of research related to the variable of Occupational Health and Safety (OHS) in these areas, especially in the area of management, is too low (Zanko and Dawson, 2012). Although Occupational Health and Safety (OHS) is seen as the main operational and strategic worry of organizations that is increasing more and more, it is generally ignored in the works of management (Zanko and Dawson, 2012). Negative effects of accidents reducing productivity and quality cause the public's image and climate of companies to be corrupted (Jewalikar and Shelke, 2013:133). Occupational accidents cause the costs related to turnover, leave of absence, and spoiled and defect goods to arise and reduce the productivity of organizations (Andersson, 1992) and organizations become disadvantages in the industrial competition (Hendrick, 1996). It is not seen to be possible for organizations to ensure higher competitive power or sustainability by choosing lower safety, health, and income level as well as a survival strategy (ILO Safety in numbers, 2003). This research model has been formed with the thought that three variables in this study will provide a great advantage to organizations in the global competition. In the domestic and foreign literature research, no study in which these three variables were handled was found. In this sense, it is thought that it will make contributions to the literature and that new scientific results about variables will be added to those obtained by now.

In this study, the effects of personnel empowerment on career satisfaction in the public health sector and the moderator role of work health safety in this effect were analyzed. Analyzes were made with the data obtained within the scope, a model of psychological empowerment compatible with workplace safety was formed and various advice was given to managers.

\section{Theory and Hypotheses}

\subsection{Psychological Empowerment}

It is seen in the literature that there are two different points of view to empowerment concept; managerial, and psychological. From a managerial point of view, empowerment is a relational structure explaining how managers (those in power) share power, knowledge, resources, and rewards with workers who lack those. From a psychological point of view, empowerment focuses on the perception of a worker towards his work rather than managerial applications involving sharing power with a worker in every area. This point of view focuses on personal opinions related to the roles of workers in the organization. Different studies on the concept of empowerment revealed that empowerment is a concept that should be dealt with as a psychological process (Menon, 2001:157). Thomas and Velthouse (1990) define psychological empowerment as a series of cognitions or states which help workers attune to their works actively and which is affected by the work environment (Spreitzer, 2007:7). Psychological empowerment means psychological states which are required for individuals to have the feel of control related to their works. The psychological point of view focuses on how it affects the work experience of workers instead of managerial focusing which is powerful at each level with workers (Spreitzer, 2008:56). 


\section{Ö. Turunç - İ. Akkoç - A. Çalışkan 12/3 (2020) 2864-2878}

Thomas and Velthouse (1990) stated that the concept of empowerment is comprised of 4 dimensions, meaningfulness, competence, choice, and impact. However, these dimensions were defined again by Spreitzer (1995b:1443-1444) as meaning, competence, autonomy, and impact. Meaning is workers' giving importance to their works and levels of thinking that their works are important. Competence is the level of confidence that workers have in the capacity of their fulfilling the role related to work successfully. Autonomy is an independent feeling of autonomy and control involving starting and managing work behaviors. Impact means the grade of belief of worker-related to the impact of his behaviors related to work on strategic, managerial, and operational results of the organization.

Menon (2001) defines the concept of empowerment as "a cognitive situation characterized by the perceived control, perceived competence, and goal internalization". Three dimensions this definition involves draws the attention to that empowerment is a perceived psychological situation. Perceived control means autonomy, accessibility to resources, authorization, and beliefs in the independence of decision-making in work planning and performance. Perceived competence means self-competence and trust related to role requests. The worker believes that he can successfully manage his routine work requests and non-routine difficulties that can arise during working. It represents the power of enabling opinions such as goal internalization, a valuable reason, duty, or vision for the future to be possible. The worker believes values the goals of an organization and is ready to act on his behalf (Menon, 2001:161).

An empowered worker has some characteristics. Firstly, an empowered worker has the awareness of making his own decisions (freedom of choosing how the works will be done). Secondly, an empowered worker knows the meaning and importance of the work he does. Thirdly, an Empowered worker has confidence in his competence. Lastly, an empowered worker is aware of his power of influence (influence the results and acceptance of his opinions) (Quin and Spreitzer, 1997:41). As a result of empowerment practices, a worker who was equipped with more authority, will service customers faster, will be able to decide without conferring with his managers, will be satisfied more when successful results have been obtained, will materialize his creative ideas, will develop new skills and will be able to show more interest to customers with more eagerly (Bowen and Lawler, 1992:31-38).

\subsection{Career Satisfaction}

The person-environment fit model faces us as an important theory explaining the concept of career satisfaction. Because it is seen as critical for the success of work and career for a long time, Person-environment fit structure draws great attention from both researchers and managers (Kristof, 1996). The person-environment fit theory (Holland, 1997), typically focuses on compatibility between workers and their environments, that is, the results of the decision-making process. Verquer et al. (2003) see work, career, and occupational success as the final result of person-environment compatibility on a large scale. According to this, while individuals are struggling for positive workplace relations and the success of a career, "they naturally want to obtain and sustain compatibility with their environments" (Lofquist and Dawis, 1991). Shortly, compatibility existing between worker and his environment increases expectations related to career and related positive results. Many definitions were made for the concept of career satisfaction by the related studies. Some of those are below;

- The reflection of worker's values and preferences related to salary, hardships, and security level may affect the evaluation of his career successes (Gattiker and Larwood, 1988).

- Career Satisfaction is a subjective measure perceiving satisfaction of workers related to their goals generally aimed at their career goals, salary goals, and promotion goals and developing new skills (Greenhaus et al., 1990).

- Career Satisfaction means satisfaction that an individual has obtained from the internal and external aspects of his career (Judge et al., 1995).

- Career Satisfaction means an individual's feeling and perception of his career referring to standards he has determined himself (Nabi, 2001).

Career satisfaction, as one of the evaluations of workers' careers specific to those, is generally the only indication of subjective career successes. (Boudreau et al., 2001; $\mathrm{Ng}$ et al., 2005). Goals of a worker from different careers (e.g. income, success, development, etc.) and his success related to career (e.g. general career success) are the evaluation of his advance towards career satisfaction. In the studies conducted in recent years (Hofmans et al., 2008), it has been found that an individual's level of income, status, and promotion used for 


\section{Ö. Turunç - İ. Akkoç - A. Çalışkan 12/3 (2020) 2864-2878}

determining his career success is less related to his reaching a certain salary level. The thing important to workers is their satisfaction resulting from themselves. The satisfaction criterion is more associated with the internal happiness feeling of a worker. Because each worker has his measures for the success of things he wants to obtain and his willingness, because they are different from requirements aimed at the success of other workers, there will be subjective measures emphasizing internal self-evaluation (happiness and interpersonal success).

In the meta-analysis study $\mathrm{Ng}$ et al. conducted (2005), they categorized predictors of objective and subjective career successes: Organizational support (e.g. Leader support, career support and training and competence development opportunities), human capital (e.g. attachment to work, work continuity, work experience, desire to transfer, international work experience, education level, career planning, and social capital), individual differences (e.g. Big five-person personality factors, proactivity, control focus, and cognitive skill) and socio-demographic condition (e.g. sex, race, marital status, and age). They revealed the connection between career satisfaction and productivity and participation in the other studies conducted. This condition is associated with higher organizational attachment and increasing creativity and innovativeness (Peluchette, 1993; Poon, 2004). Harter, Schmidt, and Hayes (2002) found that satisfaction depends on some other work results including customer satisfaction, workers' loyalty, profitability, and leave of employment. Besides, it was found in the studies that workers that are more satisfied with their works are more interested in their works and therefore, the possibility of their contributing actively to the success of their organization is higher (Peluchette, 1993; Harter et al., 2002). On the contrary, career dissatisfaction can cause workers to be laid off; Because of this, dissatisfied workers are less interested in their works and can perform badly (Korman et al., 1981).

\subsection{Occupational Health and Safety}

Despite positive progress in occupational health and safety in the last 25 years, classic health and safety hazards are still an important risk for the safety, health, and working capacity of a worker. For example, a total of between $22 \%$ and $47 \%$ of workers in EU countries are exposed to classic physical, chemical, or ergonomic hazards. As a result of work accidents, 5.000 EU workers die every year and unhealthy work conditions cause many occupational diseases. Unsuitable working conditions cause work accidents and occupational diseases, workers to suffer, and lose their jobs (ILOb).

In addition to classic loads for occupational health and safety, many new risks related to fast change in worklife, new work methods, new technologies, new materials, and new objects, and the development of new work organizations bring new hardships in the area of safety. However, new technologies provide new opportunities for better safety and health in the workplace. According to data from the Association of Dublin, 23-60 \% of EU workers are exposed to psychosocial hazards such as high work tempo, very short deadlines, time pressure, stress, and tiredness, etc. Also, reasons such as insecurity that employment and short term and labor agreements cause comprise an important stress factor for the important part of workers (ILOa). The purpose of occupational health and safety within this scope is to form the standards which will ensure health and safety in an organization and to reduce diseases and deaths, injuries related to work (Bhagawati, 2015: 91).

The concept of occupational health and safety (OHS) is tried to be expressed by combining definitions of words of occupation, safety, and health. (Brueggmann et al., 2001). According to International Labor Organization (ILO) and World Health Organization, occupational health and safety is a branch of science, aiming at bringing good social, mental, and occupational conditions of workers to the level as high as possible and sustaining these conditions, protecting workers from harmful factors in the working environment within the scope, and placing them in a suitable position (Barnett-Schuster, 2008:2). In another expression, OHS is defined as "by removing hazardous conditions for occupational factors and occupational health safety, protecting and improving the health of workers, increasing physical, mental and social welfare of workers, developing their work capacity and supporting sustainability, in addition to these, enabling them to develop socially and professionally in the working environment" (Tadesse and Admassu, 2006:4). The concept of occupational health safety involves mental, emotional, and physical welfare related to workers performing his work (Montero et al., 2009). 


\section{Ö. Turunç - İ. Akkoç - A. Çalışkan 12/3 (2020) 2864-2878}

The effect of psychosocial work factors on organizational behavior is well-known in the literature. The studies have shown that workers develop a series of consistent perceptions and expectations based on assessments based on social and organizational conditions in which they carry out their works (Gyekye, 2014:199). If the working environment has characteristics such as agronomy, modern information and communication technologies, environmental compatibility and secure working environment, etc., it provides comfort (welfare) to workers and so provides a better working environment causing them to show the best performance (Azril et al., 2010:65).

OHS contributes to the compatibility of products by enabling the required conditions to be performed precisely (De Oliveira et al., 2002). Besides, it is heavily associated with anxiety level related to OHS within the context of production, that is, in terms of productivity work systems and performers of workers (Erdinç and Yeow 2011). Because health problems of workers may affect the quality or credibility of product and service, outputs that organizations obtain becomes vulnerable to hazards. The legal requirements for occupational health are not fulfilled cause organizations to lose their charm in terms of skillful workers and loyalty of the customer to be lost in terms of the customer. Such a condition causes organizations to encounter negative economic results (Miller and Haslam, 2009). The health of workers is associated with the cost of production, because, accidents cause production expenditures to increase because of the costs of sick leave, compensation, and replacement of workers. (Dollard and Neser, 2013:115).

Unsafe working conditions deteriorate the industrial climate more and weaken the morale and motivation of workers as well as the identification of workers with business owners and managers. As a result, such conditions cause workers to quit and organizations find it hard to find a qualified worker. Therefore, occupational health and safety benefit organizations because of the advantages of keeping workers healthy and productive. Accidents affect the reputation and image of a company negatively (Smallman and John, 2001). So, it may be said that work health and safety is a management function related to increasing the quality and productivity of an organization (Friend and Kohn, 2007:2).

It was seen that workers with constructive opinions related to the organizationally safe working environment have higher levels of work satisfaction. So, it was determined that they are more compatible with safety management policies and rates of accidents are relatively lower. On the contrary, it was found that because workers having behavior experiences been hard on them and negative evaluations related to safety climate, they are less happy with their works, they are less adhered to safe working and accidents happen more frequently (Gyekye and Haybatollahi, 2014).

\subsection{Relationships between Variables of Psychological Empowerment, Career Satisfaction, Occupational Health and Safety}

Empowerment, Career Satisfaction, Occupational Health and Safety

The theoretical base and hypotheses of this study are based on the social exchange theory. (Blau, 1964; Gouldner, 1960). There is a reciprocity norm, which requires that workers respond positively to positive behavior they get from organizational management, on the base of this theory. Contrary to economic change in which behavior is determined with a certain agreement between worker and organization, social change is comprised of disorderly, uncertain, and unofficial agreements, which are based on trust between two parties. According to social exchange theory, individuals who are behaved positively by other people feel responsibility and indebtedness about responding positively and with positive behavior. Various applications to social exchange theory for empowerment implementations carried out within the framework of reciprocity create common visions aimed at the future and increase workers' adherence to their work and enable their feelings of self-confidence and self-pride and responsibility to develop (Robbins, 2003:479). Applications carried out within the framework of social exchange theory and reciprocity principle for health and safety implementations provide health and well-fare of workers and increase the interest of these workers to an organization and cause their feeling of adherence to the organization to form (Mearns at al., 2010:1446). Within this scope, social exchange is one of the important predictors of attitudes and behaviors of workers such as safety performances (Gyekye, 2005; Gyekye and Salminen, 2007), personnel empowerment, and career satisfaction, etc. 


\section{Ö. Turunç - İ. Akkoç - A. Çalışkan 12/3 (2020) 2864-2878}

According to Spreitzer (1995b), when workers perceive that they have control over their work lives, there is psychological empowerment. Psychological empowerment is not a constant personality trait. It is comprised of cognitions shaped by the working environment. Psychological empowerment increases personal control perception and motivates them to participate in works. This leads to positive managerial and organizational results (Quinn and Spreitzer, 1997). In a study conducted, meaning and competence dimensions of psychological empowerment predicts career development intentions (Kraimer et al., 1999). In another study conducted, a positive relationship between psychological empowerment and career satisfaction was determined. (Joo and Lim, 2013).

Workers feeling more powerful become more motivated to show effective performance (Chen and Klimoski, 2003; Seibert at al., 2004; Chen at al., 2007). Results of many studies conducted show that psychological empowerment probably increases performance because people overlap job definitions and they are more effective and innovative in their works (Spreitzer, 2008:62).

Empowerment is also more associated with organizational citizenship behavior (Wat and Shaffer, 2004). A worker may transfer his determination about psychological empowerment to others and so, may lead to behaviors that cause safety results (Laszlo and Krippner, 1998). The perception that workers have been freed in determining their actions with psychological empowerment (Spreitzer, 1995a; Spreitzer, 1995b) leads to suitable safety behavior that will be able to cause higher working life quality (Laszlo and Krippner, 1998). In a study conducted, it was found that there is a negative relationship between empowerment and unsafe behaviors and safety accidents (Hechanova-Alampay and Beehr, 2001:279). When literature was scanned, it was found that there has been no study dealing with the relationships between career satisfaction and work safety. This study was conducted to complete this deficiency. The hypotheses below were suggested in accordance with social exchange theory logic and literature scan above;

H1 There is a positive relationship between psychological empowerment and career satisfaction.

H1a There is a positive relationship between goal internalization and career satisfaction.

$\mathrm{H} 1 \mathrm{~b}$ There is a positive relationship between perceived competence and career satisfaction

H1c There is a positive relationship between perceived control and career satisfaction.

$\mathrm{H} 2$ There is a positive relationship between psychological empowerment and work safety.

H3 There is a positive relationship between work safety and career satisfaction.

H4 Work safety perception has a moderator effect in the effect of psychological empowerment on the career satisfaction of workers.

H4a Work safety perception has a moderator effect in the effect of goal internalization on the career satisfaction of workers.

H4b Work safety perception has a moderator effect in the effect of perceived competence on the career satisfaction of workers.

H4c Work safety perception has a moderator effect in the effect of perceived control on the career satisfaction of

\section{Method}

\subsection{Data Collection Method and Sampling}

The questionnaire method was used as a data collection tool in this study. The questionnaire form is comprised of two parts and a total of 33 questions. All the measurement tools and the developing and using process are explained in part 3.1. There are questions about demographic information in the first part and those about the independent variable of psychological empowerment (PE) and the dependent variable of Career Satisfaction (CS) and lastly, the variable of work safety in the second part. The questionnaire was applied face to face in the first half of 2019.

Universe and samples of the empiric study designed to determine the effect of psychological empowerment on career satisfaction and the role of work safety applications in this relationship involve workers working in 


\section{Ö. Turunç - İ. Akkoç - A. Çalışkan 12/3 (2020) 2864-2878}

public health institutions in Antalya/Turkey. A simple random sampling technique was utilized to obtain data. The data are collected in 2019 from all the public health sector's employees working in Antalya/Turkey including expert doctors, regular doctors, nurses, midwives, and other health personals by face to face application. About $43,6 \%$ of the participants under investigation are between $36-45$ years old, $68,3 \%$ of the participants are female and $76,2 \%$ are married. $31.3 \%$ of the participants are undergraduate and $29,5 \%$ are nurses. The detailed information is presented in Table 1.

Various analyses conducted to the model formed under data of utilizable 420 questionnaires $(n=420)$ obtained from these samples were made. It was seen that size of samples involving 420 people can represent the universe with .95 reliabilities and .05 sampling error (Yazıcıŏ̆lu and Erdoğan, 2004:49-50).

Table 1. Respondent profile $(n=420)$

\begin{tabular}{|c|c|c|}
\hline Variables & Frequency & Percentage \\
\hline \multicolumn{3}{|l|}{ Age } \\
\hline 25 and under & 36 & $8,60 \%$ \\
\hline $26-35$ & 108 & $25,70 \%$ \\
\hline $36-45$ & 183 & $43,60 \%$ \\
\hline 46 and above & 93 & $22,10 \%$ \\
\hline Total & 420 & $100 \%$ \\
\hline \multicolumn{3}{|l|}{ Sex } \\
\hline Female & 287 & $68,30 \%$ \\
\hline Male & 133 & $31,70 \%$ \\
\hline Total & 420 & $100 \%$ \\
\hline \multicolumn{3}{|l|}{ Education } \\
\hline High school & 94 & $22,40 \%$ \\
\hline Associate & 132 & $31,40 \%$ \\
\hline Undergraduate & 158 & $37,60 \%$ \\
\hline Graduate & 18 & $4,30 \%$ \\
\hline Doctorate & 18 & $4,30 \%$ \\
\hline Total & 420 & $100 \%$ \\
\hline \multicolumn{3}{|c|}{ Marital status } \\
\hline Single & 100 & $23,80 \%$ \\
\hline Married & 320 & $76,20 \%$ \\
\hline Total & 420 & $100 \%$ \\
\hline \multicolumn{3}{|l|}{ Profession } \\
\hline Expert doctor & 16 & $3,80 \%$ \\
\hline Regular doctor & 17 & $4 \%$ \\
\hline Nurse & 124 & $29,50 \%$ \\
\hline midwife & 72 & $17,10 \%$ \\
\hline $\begin{array}{l}\text { Other Health } \\
\text { Personals }\end{array}$ & 191 & $45,50 \%$ \\
\hline Total & 420 & $100 \%$ \\
\hline
\end{tabular}

After confirmatory factor analyses, hypotheses and moderator effects were tested with three-step hierarchical regression analysis suggested by Baron and Kenny (1986). Moderator effects are tested with regression curves. Hypotheses and structured interview model are presented in Figure 1. 


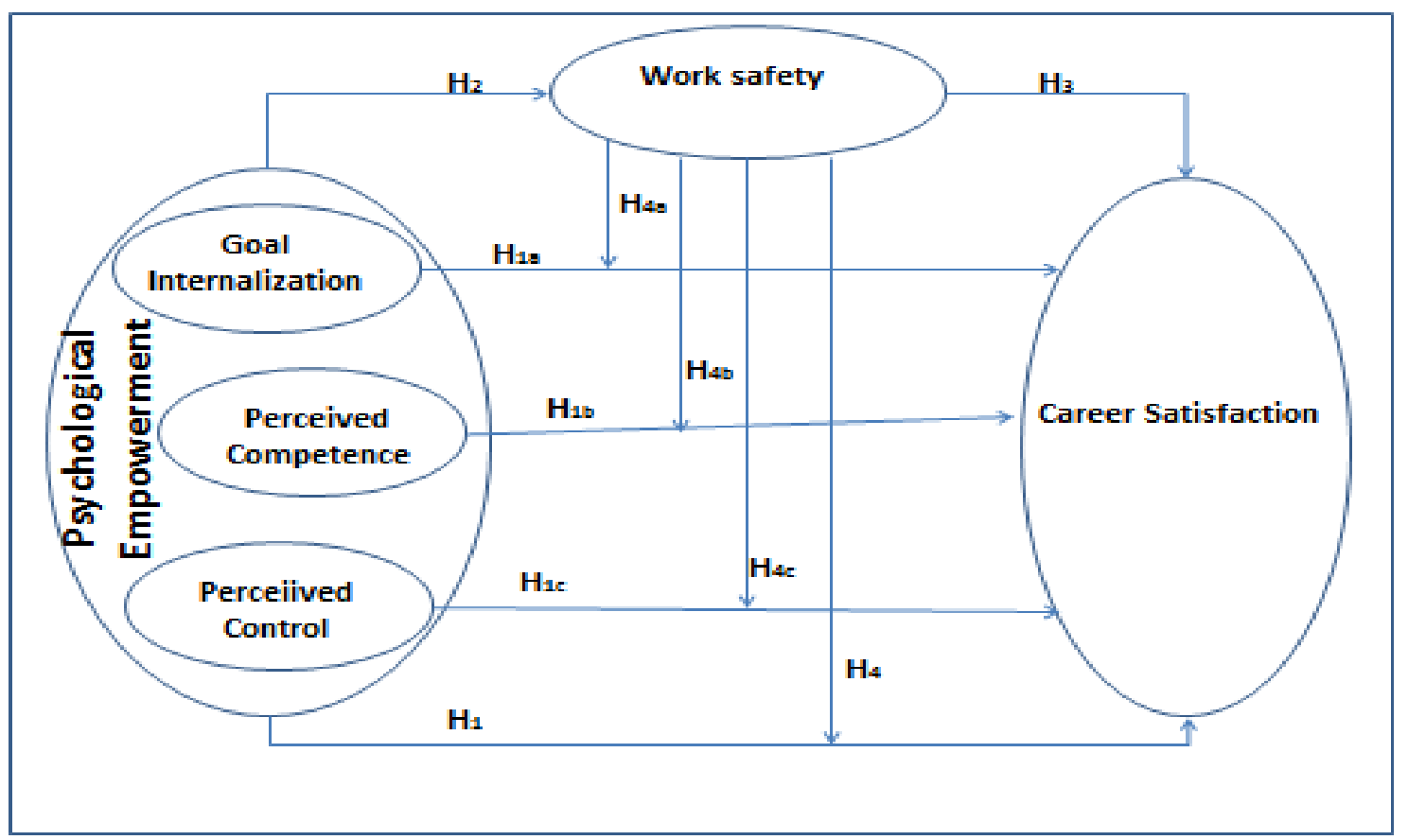

Figure 1. Research Model and Hypotheses

\subsection{Scales of the Research:}

\subsubsection{Psychological Empowerment Scale (PE)}

The scale with 3 dimensions and 15 items compiled from various research which was prepared by Menon (2001), whose validity studies were conducted, was used to determine the level of psychological empowerment. Cronbach alfa reliability coefficients were found to be $.86, .78, .86$ consecutively in the scale dimensioned as Goal Internalization (GI), perceived competence (PCP), and perceived control (PC). Answers in the scale were taken with the 5-item Likert Scale ( $1=$ Strongly Agree, $5=$ Strongly Disagree). First of all, exploratory factor analysis was made to test the structural validity of the psychological empowerment scale. It was found as a result of the analysis that data fitted the 3-factor structure of the original scale. In the scale structured in a single dimension, all items were found to have sufficient factor loading. It was found that the $\mathrm{KMO}$ analysis result of the three-factor scale was .88 , the Barlett test was meaningful $(\mathrm{p}=.000)$ and explained variance was 68. After these analyses, confirmatory factor analysis was made with the AMOS software package. It was found as a result of 1 . level SEM factor analysis that data fitted a 3-dimensional structure of the scale. The values of goodness of fit of the scale are presented collectively with the findings of other scales in Table 1. As a result of reliability analysis, goal Internalization perceived competence and perceived control and total Cronbach Alpha Reliability Coefficient of the total scale are found to be $.87, .86, .85, .88$ respectively.

\subsubsection{Career Satisfaction Scale (CS)}

5-item scale developed by Greenhaus, Parasurman and Wormley (1990) and used by Hofmans, Dries and Pepermans (2008) was used to determine subjective career satisfaction. Answers were taken with the 5-item Likert Scale (1=Strongly Agree, 5=Strongly Disagree). The scale was validated by Avcı and Turunç (2011) in Turkish. As a result of reliability analyses carried out by Hofmans et al., (2008), the Cronbach alfa reliability coefficient was determined to be .74. First of exploratory factor analysis was made to test the structural validity of the career satisfaction scale. It was found as a result of the analysis that data fitted the single-factor structure of the original scale. 1 item (T3) was removed from the analysis because of low factor loading. It was found that result of $\mathrm{KMO}$ analysis was .77, the Barlett test was significant $(\mathrm{p}=.000)$. After these analyses, confirmatory factor analysis was made with the AMOS software package. As a result of the factor analysis, it was found that data fitted the single-factor structure of the scale. The goodness of fit values of the scale is presented with the findings of other scales in Table 1. As a result of the reliability analyses conducted, it was found that the Cronbach alfa reliability coefficient was .80 . Variance single-dimensional scale explained was determined to be .55 . 


\section{Ö. Turunç - İ. Akkoç - A. Çalışkan 12/3 (2020) 2864-2878}

\subsubsection{Work Safety (WS)}

In order to determine the perception of workers about occupational health and safety, 10 items dimension of the scale of work safety with 50 questions that Hayes et al. (1998) developed, was used. Answers in the scale were taken with the 5-item Likert Scale ( $1=$ Strongly Agree, $5=$ Strongly Disagree). In this study, the scale used in the study of Gyekye and Salminen (2005) is validated in Turkish and used. It was found in the analyses made by Gyekye and Salminen (2007) that the Cronbach alfa reliability coefficient was.94.

First of all, exploratory factor analysis was made to test the structural validity of the work safety scale. As a result of the analysis, it was found that data fitted the single-factor structure of the original scale. The result of $\mathrm{KMO}$ analysis was .90 and the Barlett test was significant $(\mathrm{p}=.000)$. After these analyses, confirmatory factor analysis was made with the AMOS software package. As a result of the factor analysis, it was found that data fitted the single-factor structure of the scale. The goodness of fit values of the scale is presented with the findings of other scales in Table 1 . As a result of the reliability analyses conducted, it was found that the Cronbach alfa reliability coefficient was .92 . Variance single-dimensional scale explained was determined to be .65 .

\subsection{Validity and Reliability of the Scales}

SPSS software package was used for the reliability tests of the scales, and the AMOS software package for confirmatory factor analyses and structural equity modeling. Cronbach Alpha coefficients were determined for establishing the reliability of the scales, and confirmatory factor analyses were made to determine whether they are valid. Findings related to CFA are in table 1 . After then, correlations between variables were determined and are presented in Table 2.

Table 2. The Goodness of fit values of the scales as a result of confirmatory factor analysis.

\begin{tabular}{|c|c|c|c|c|c|c|c|c|c|}
\hline Değişkenler & $\mathrm{X}^{2}$ & df & $\begin{array}{c}\text { CMIN/ } \\
\text { DF } \\
\leq 5\end{array}$ & $\begin{array}{l}\text { GFI } \\
\geq .85\end{array}$ & $\begin{array}{c}\text { AGFI } \\
\geq .80\end{array}$ & $\begin{array}{l}\text { CFI } \\
\geq .90\end{array}$ & $\begin{array}{l}\text { NFI } \\
\geq .90\end{array}$ & $\begin{array}{l}\text { TLI } \\
\geq .90\end{array}$ & $\begin{array}{c}\text { RMSEA } \\
\leq .08\end{array}$ \\
\hline $\begin{array}{l}\text { 1. Psychological } \\
\text { empowerment(PE) }\end{array}$ & 286,4 & 82 & 3,49 & 0,90 & 0,86 & 0,94 & 0,91 & 0,92 & 0,08 \\
\hline 2. Career satisfaction (CS) & 2,10 & 1 & 2,1 & 0,99 & 0,97 & 0,99 & 0,99 & 0,99 & 0,05 \\
\hline 3. Work safety (WS) & 124,9 & 30 & 4,1 & 0.96 & 0.93 & 0.98 & 0.97 & 0.97 & 0.06 \\
\hline
\end{tabular}

Pearson correlations were calculated to determine the relations between the variables. (Table 3). In addition, reliability findings are presented in brackets at the end of the rows. As a result of the analysis, it is seen that personnel empowerment has significant relations with career satisfaction, which is a dependent variable and work safety.

Table 3. Average, S. Deviation and Correlation Values

\begin{tabular}{lcccccccc}
\hline Variables & Mean & S.D & $\mathbf{1}$ & $\mathbf{2}$ & $\mathbf{3}$ & $\mathbf{4}$ & $\mathbf{5}$ & $\mathbf{6}$ \\
\hline 1. Career Satisfaction(CS) & 3,09 & 0,99 & $(, 80)$ & & & & & \\
2.Work Safety (WS) & 3,20 & 1,07 & -.01 & $(, 92)$ & & & & \\
3.Goal internalization(GI) & 3,94 & 0,82 & .08 & -.03 & $(, 87)$ & & & \\
4. Perceived competence & 3,71 & 0,79 & $.25^{* * *}$ & .03 & $.54^{* * *}$ & $(, 86)$ & & \\
(PCP) & 4,23 & 0,73 & $.14^{* *}$ & .03 & $45^{* * *}$ & $.40^{* * *}$ & $(, 85)$ & \\
5. Perceived control (PC) & 3,09 & 0,99 & $.20^{* * *}$ & .01 & $.83^{* * *}$ & $.81^{* * *}$ & $.75^{* * *}$ & $(, 88)$ \\
6. Psychological & empowerment(PE) & & & & & & &
\end{tabular}

Not: Alpha coefficients are in parentheses.

${ }^{* *} p \leq .01{ }^{* * *} p \leq .001$ 


\subsection{Findings}

Moderator effects were investigated with three-step hierarchic regression analysis suggested by Baron and Kenny (1986). Moderator effects were analyzed with regression curves.

In this study, which aimed at determining the effect of PE on CS and the moderator role of WS in this effect, hierarchic regression analyses were made to test the hypotheses.

In the hierarchic regression analysis made to test the hypothesis, PE and its three dimensions (GI, PCP, PC) were included in the model as independent variables separately, career satisfaction as a dependent variable, and work safety (OC) as a moderator variable. The results of analyses related to moderator analyses are in Table 4. When PE, GI, PCP, PC, and WS and CS were being included in the model, they were centralized (Cohen at al., 2003).

Table 4. Results of Moderator Effect Analysis

\begin{tabular}{|c|c|c|c|c|c|c|c|}
\hline \multirow[b]{2}{*}{ Step } & \multicolumn{4}{|c|}{ Career satisfaction (CS) } & \multicolumn{3}{|c|}{ Career satisfaction (CS) } \\
\hline & 1 & 2 & 3 & Step & 1 & 2 & 3 \\
\hline $\mathrm{PE}$ & $.20^{* * *}$ & $.20^{* * *}$ & $.18^{* * *}$ & GI & .08 & .08 & .07 \\
\hline WS & & -.01 & -.009 & WS & & -.01 & -.003 \\
\hline PExWS & & & $-.09^{*}$ & GIxWS & & & $-.11^{*}$ \\
\hline$A R^{2}$ & .04 & 04 & .04 & $A R^{2}$ & .005 & .003 & .02 \\
\hline \multirow[t]{2}{*}{$\Delta F$} & $15,9^{* * *}$ & $7,9^{* * *}$ & $6,5^{* * *}$ & $\Delta F$ & 2,9 & 1,4 & 2,7 \\
\hline & \multicolumn{4}{|c|}{ Career satisfaction (CS) } & \multicolumn{3}{|c|}{ Career satisfaction (CS) } \\
\hline Step & 1 & 2 & 3 & Step & 1 & 2 & 3 \\
\hline $\mathrm{PCP}$ & $.26^{* * *}$ & $.26^{* * *}$ & $.25^{* * *}$ & PC & $.14^{* *}$ & $.14^{* *}$ & $.13^{*}$ \\
\hline WS & & -.02 & -.02 & WS & & -.01 & -.01 \\
\hline PCPxWS & & & $-.11^{*}$ & PCxWS & & & -.05 \\
\hline$A R^{2}$ & .06 & 06 & .08 & $A R^{2}$ & .02 & .02 & .02 \\
\hline$\Delta F$ & $26,6^{* * *}$ & $13,4^{* * *}$ & $10,9^{* * *}$ & $\Delta F$ & $7,6^{* *}$ & $3,8^{*}$ & $2,9^{*}$ \\
\hline
\end{tabular}

${ }^{*} p \leq .05,{ }^{* *} p \leq .01,{ }^{* *} p \leq .001$

The moderator variable is a variable affecting the power and direction of the relationship between the dependent and independent variables (Baron and Kenny, 1986: 1174). According to multiple regression analyses in Table 3, the moderator effect of WS was examined. As a result of the analysis, it was seen that WS has a moderator effect on the relation between PE and CS $(\beta=-.09, p \leq 05)$. And also it was seen that WS has a moderator effect on the relationship between GI and CS $(\beta=-.11, p \leq 05)$. The last finding of the analyses is that WS has a moderator effect on the relationship between PCP and CS $(\beta=-.11, p \leq 05)$ and WS does not have a moderator effect on the relationship between PC and CS $(\beta=-.05, p>05)$. Also, the process suggested by Cohen et al. (2003) was followed to examine the direction of the relation more detailedly. Within this scope, when work safety, which is the moderator variable, was low and high, the significance of the relationships between PE and CS, GI and CS, and PCP and CS was tested (Aiken and West, 1991).

As seen in Figure 2 in which regression curves explaining moderator effects in detail are shown collectively, although the relation between PE and CS is significant when WS perception is both low and high, it is seen that PE-CS interaction is higher when WS is high. As a result of PE-WS interactions, it was found that the whole model explains $4 \%$ of the variance. So, Hypothesis 4 was supported. That is, WS has a moderator effect within the scope of this relationship. As a result of the analyses, it was seen that the H1 hypothesis was supported but the $\mathrm{H} 3$ hypothesis was not.

As seen in Figure 2, although the relationship between GI and CS is significant when WS perception is both low and high when WS is low, GI increases CS, and on the contrary to such condition, when WS is low, GI reduces CS. As a result of PCP-WS interactions, $2 \%$ of the variance of the whole model was explained. So, Hypothesis 4a was supported. That is, WS has a moderator effect within the scope of this relationship.

As seen in Figure 2, although the relationship between PCP and CS is significant when WS perception is both high and low when WS is low, PCP increases CS, on the contrary, when WS is low, GI reduces CS. As a result 


$$
\text { Ö. Turunç - İ. Akkoç - A. Çalışkan 12/3 (2020) 2864-2878 }
$$

of PCP-WS interactions, $8 \%$ of the variance of the whole model was explained. So, Hypothesis 4 a was supported. That is, WS has a moderator effect within the scope of this relationship.
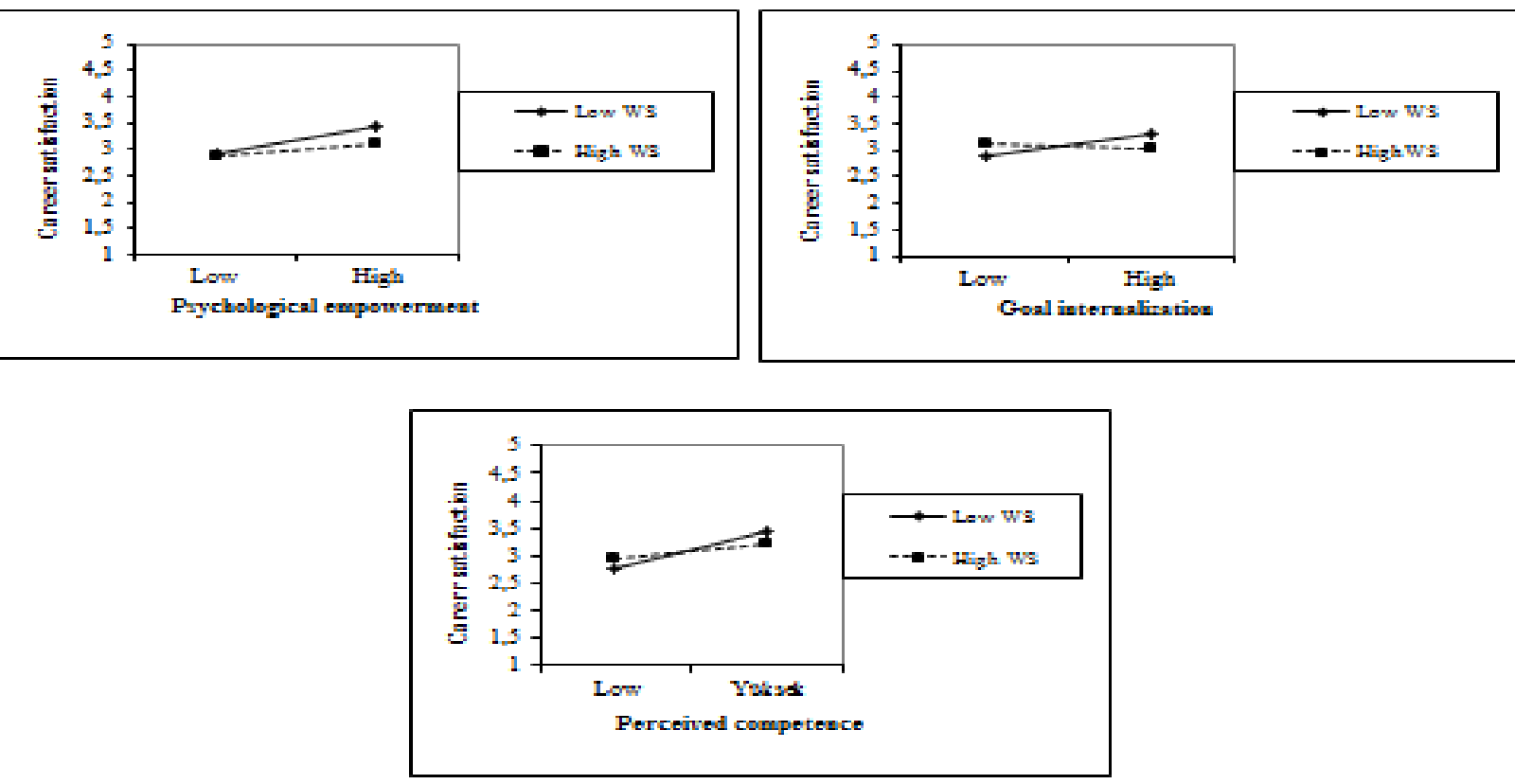

Figure 2: Results of Moderator Effect of WS in the relationship between PE/GI/PC-CS

Within the scope of findings obtained as a result of analyses made, test results of the hypothesis are presented in Figure 3 collectively.

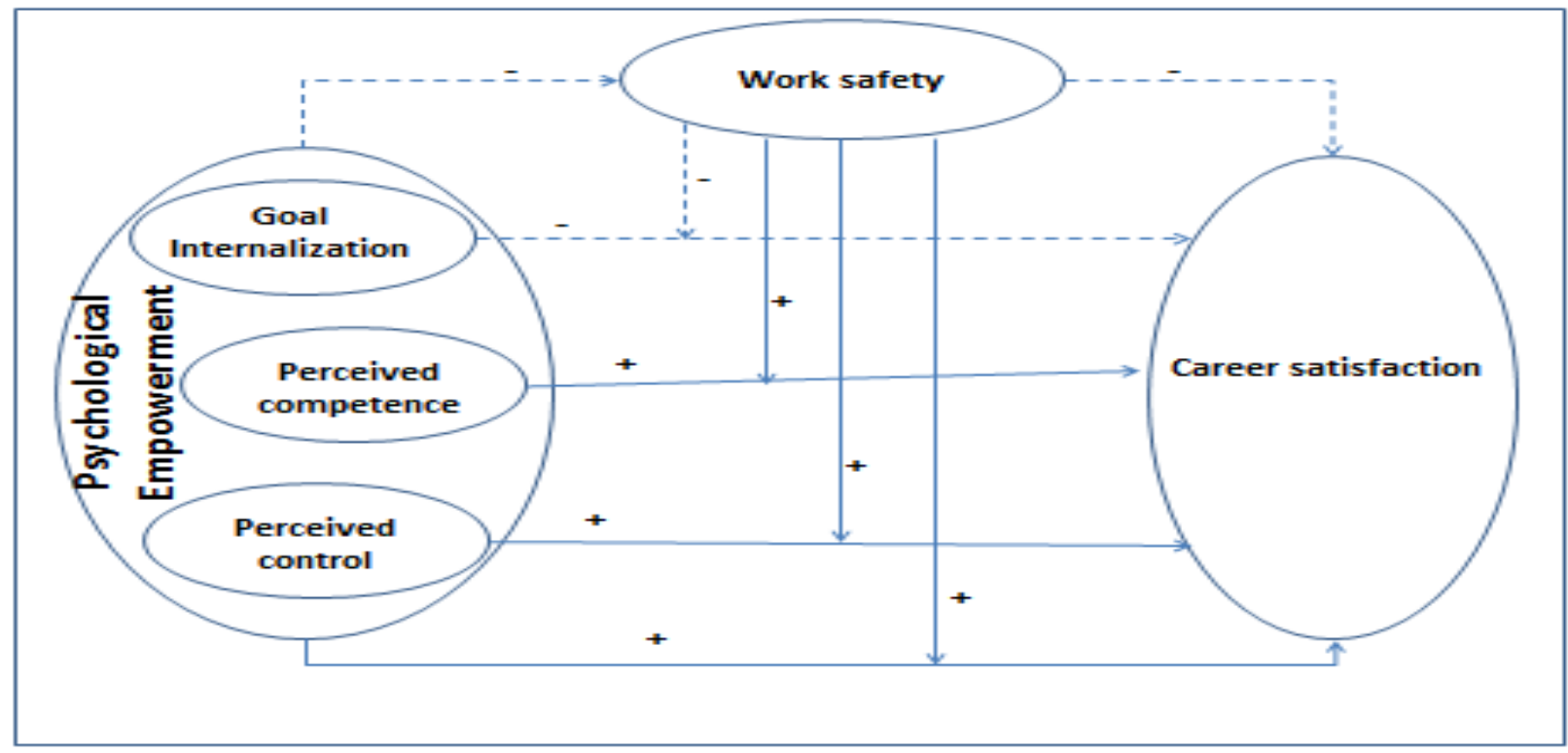

Figure 3. Test Results of Hypotheses

\section{Discussion}

In this study, the effect of psychological empowerment on career satisfaction and the moderator role of work safety in this effect was analyzed. In this study, the effects of variables included in the analysis of career satisfaction and work safety were tried to be explained with the help of hierarchic regression analysis.

After the results of the analyses were examined, it was determined that psychological empowerment and two out of its three dimensions (except for goal internalization) increase the career satisfaction of workers 


\section{Ö. Turunç - İ. Akkoç - A. Çalışkan 12/3 (2020) 2864-2878}

significantly. This finding is compatible with the studies conducted by Kraimer et al., (1999) and Joo and Lim (2013). The analyses made found that psychological empowerment (total) does not affect the work safety perception of workers significantly. Although this is an unexpected finding, it is the desired situation in which a variable whose moderator effect is being investigated does not have a relationship with dependent and independent variables or have a relationship at a low level. Indeed, it was found that the perception of work safety does not have a significant relationship with career satisfaction. Although there exists such an expected relationship, being relationshipless which is sought in the moderator variables has compensated this deficiency. Findings obtained are compatible with the study conducted by Healy (2017).

Results of advanced level analyses made showed that the moderator effect of work safety perception in the effect of psychological empowerment and its dimensions on career satisfaction exists except for the relationship between perceived control and career satisfaction. That is, work safety perception moderates the effect of psychological empowerment on the career satisfaction of workers. The effects of significant moderator obtained as a result of advanced level analyses were examined when work safety perception was high and low. When work safety perception is low, the effect of psychological empowerment on career satisfaction is high in a positive direction. Although this finding is an unexpected finding at first glance, in organizational behavior studies, it matches up to the findings that sometimes relations are stronger when there are negative variables. In fact, on the other side of the fence, whereas the existence of work safety in the working environment may cause the effects of other variables to be ignored for career satisfaction, it is thought that behaviors aimed at empowering workers may be perceived more positively by workers and maybe a motivation tool causing them to be able to ignore many negative conditions in cases when work safety perception is low. Within this context, this is a finding which was unexpected but was considered positive and is a strange one of the study in terms of the literature.

In general, relationships between psychological empowerment and job satisfaction are frequently included in organizational behavior studies. There are not enough studies on this topic. The outcomes of this paper indicate that psychological empowerment in the health sector has a positive effect on career satisfaction. In essence; this paper shows that occupational health practices play an important role in the factors affecting the career satisfaction of healthcare professionals in today's business life. Henceforth, this paper suggests that practices that will make employees feel safe will have to be more important to provide a satisfied and efficient employee in changing business life. This implies that managers should give more places to OHS practices to change the attitudes and behaviors of employees, especially in business environments that have risks such as the health sector.

There are various limitations of the study. Firstly, a cross-sectional design was used. Therefore, it becomes harder to be able to control the relationships of variables and determine their causalities. In order to evaluate causality relationships, longitudinal research is required. Longitudinal designs should be used to analyze the relations between psychological empowerment, career satisfaction, and workplace safety in the studies ahead. Secondly, the scale which restricts the answers of participants according to items used in the scale and limits the richness and diversity of possible answers were used. Lastly, considering the number of workers in the health sector, the number of samples can be increased and various answers may be taken. The research ahead should use more than one data source and method to remove the limitations above because a cross-sectional questionnaire method limits the research with a part of the target group. Besides, more data are required to be collected from different regions and different sectors to increase the generalizability of the study.

\section{Rererencess}

Abele, A.E., and Spurk, D. (2009). The longitudinal impact of self-efficacy and career goals on objective and subjective career success, Journal of Vocational Behavior, Vol. 74: 53-62.

Aiken, L.S., and West, S.G. (1991) Multiple regression: Testing and interpreting interactions. Los Angeles, CA: Sage Andersson, E.R. (1992). Economic evaluation of ergonomic sulution: part 1-guidelines for the practioner, International Journal of Industrial Ergonomics, Vol. 10, No. 1: 161-171.

Avcl, U., and Turunç, Ö. (2012). Dönüşümcü liderlik ve örgüte güvenin kariyer memnuniyetine etkisi lider üye etkileşiminin aracılık rolü, Uluslar Arası Alanya İşletme Fakültesi Dergisi, Vol. 4, No. 2: 45-55. 


\section{Ö. Turunç - İ. Akkoç - A. Çalışkan 12/3 (2020) 2864-2878}

Azril, M.S.H, Jegak, U., Asiah, M., Azman, A.N., Bahaman, A.S., Jamilah, O., and Thomas, K. (2010). Can Quality of Work Life Affect Work Performance Among Government Agriculture Extension Officers? A Case from Malaysia. Journal of Social Science, 6 (1), 64-73.

Bandura, A. (2001). Social cognitive theory: an agentic perspective, Annual Review of Psychology, Vol. 52: 1-26.

Barnett-Schuster, C. (2008). Fundamentals of International Occupational Health and Safety Law. Aberdeen University Press.

Baron, R.M., and Kenny, D.A. (1986). The moderator mediator variable distinction in social psychological research: conceptual, strategic, and statistical considerations, Journal of Personality and Social Psychology, Vol. 51:1173-1182.

Bhagawati, B. (2015). Basics of occupational safety and health. Journal of Environmental Science, Toxicology and Food Technology, Vol. 9, No. 8: 91-94.

Blau, M. (1964) Exchange and power in social life. New York, NY, USA: Wiley.

Boudreau, J.W., Boswell, W.R., and Judge, T.A. (2001). Effects of personality on executive career success in the United States and Europe, Journal of Vocational Behavior, Vol. 58: 53-81.

Bowen, D.A., and Lawler, E.F. (1992). The Empowerment of Service Workers: What, Why, How, And When, Sloan Management Review, Vol. 33 No. 3: 31-39.

Brueggmann, M., Roetting M., and Luczak H. (2001). International comparison of occupational safety and health research-a review based on published articles, International Journal Of Occupational Safety And Ergonomics, Vol. 7, No. 4: 387-401

Chen, G., and Klimoski, R.J. (2003).The impact of expectations on newcomer performance in teams as mediated by work characteristics, social exchanges, and empowerment, Academy of Management Journal, Vol. 46, No. 5: 591-607.

Chen, G., Kirkman, B.L., Kanfer, R., Allen, D., and Rosen, B. (2007). A multilevel study of leadership, empowerment, and performance in teams, Journal of Applied Psychology, Vol. 92, No. 2: 331-346.

Cohen, J.; Cohen, P.; West, S. G.; Aiken, L. S. (2003). Applied multiple regression/correlation analysis for the behavioral sciences (3rd edition). Mahwah, NJ: Erlbaum.

Conger, J. A., and R. N. Kanungo. (1988). The empowerment process: integrating theory and practice, Academy of Management Review. Vol. 13, No. 3, pp. 471- 482.

De Oliveira, M.J.C. and Coelho, D.A. (2002).The integration of the standards systems of quality management, environmental management and occupational health and safety management, International Journal of Production Research, Vol. 40: 3857-3866.

Dollard, M.F., and Neser, D.Y. (2013). Worker health is good for the economy: Union density and psychosocial safety climate as determinants of country differences in worker health and productivity in 31 European countries, Social Science and Medicine, Vol. 92: 114-123. doi:10.1016/j.socscimed.2013.04.028.

Erdinc O., and Yeow P.H.P. (2011). Proving external validity of the relationship between ergonomics and quality through review of real-world case studies, International Journal of Production Research, Vol. 49, No. 15: 949-962.

Friend, Mark A., and Kohn, James P. (2007) Fundamentals of Occupational Safety and Health. Maryland: Government Institutes.

Gattiker, U., and Larwood, L. (1988). Predictors for manager's career mobility, success and satisfaction, Human Relations, Vol. 41, No. 8: 569-591.

Gouldner, A.W. (1960). The norm of reciprocity: a preliminary statement, American Social Review. Vol. 25, No. 2: 161-78.

Greenhaus, J.H., S. Parasuraman and Wormley, W.M. (1990). Effects of race on organizational experiences, job performance evaluations and career outcomes, Academy of Management Journal, Vol. 33, No. 1: 64-86.

Gyekye, S. A, and Haybatollahi M. (2014). Relationship Between Organizational Justice and Organizational Safety Climate: Do Fairness Perceptions Influence Employee Safety Behaviour?' International Journal of Occupational Safety and Ergonomics, Vol. 20, No. 2: 199-211, doi: 10.1080/10803548.2014.11077045

Gyekye, S.A. (2005). Workers' Perceptions of Workplace Safety and Job Satisfaction, International Journal of Occupational Safety and Ergonomics, Vol. 11, No. 3: 291-302.

Gyekye, S.A., and Salminen S. (2007). Workplace safety perceptions and perceived organizational support: do supportive perceptions influence safety perceptions?, International Journal of Occupational Safety and Ergonomics, Vol. 13, No. 2: 189-200. 


\section{Ö. Turunç - İ. Akkoç - A. Çalışkan 12/3 (2020) 2864-2878}

Harter, J.K., F.L. Schmidt and Hayes. T.L. (2002). Business-Unit-Level Relationship Between Employee Satisfaction, Employee Engagement, And Business Outcomes: A Meta-Analysis, Journal of Applied Psychology, Vol. 87, No. 2: 268-279.

Hayes, B.E., Perander, J., Smecko, T., and Trask, J. (1998). Measuring perceptions of workplace safety: Development and validation of the Workplace Safety Scale', Journal of Safety Research, Vol. 29, No. 3: 145-161.

Healy, C. (2017) Influence of Psychological Empowerment, Leadership, and Climate on Safety Outcomes (Doctoral Dissertation), Walden University, College of Social and Behavioral Sciences, Washington Minneapolis.

Hechanova-Alampay, R. H., and Beehr, T. A. (2001). Empowerment, span of control and safety performance in work teams after workforce reduction, Journal of Occupational Health Psychology, Vol. 6: 275-282.

Hendrick, H.W. (1996). The ergonomics of economics is the economics of ergonomics. Proceedings of the Human Factors and Ergonomics, Society 40th Annual Meeting; Human Factors and Ergonomics Society; Philadelphia: 1-10.

Hofmans, J., Dries, N., and Pepermans, R. (2008). The career satisfaction scale: response bias among men and women, Journal of Vocational Behavior, Vol. 73: 397-403.

Holland, J.L. (1997) Making vocational choices (3rd Ed.). Odessa, Fl: Psychological Assessment Resources.

ILO (a) (International Labor Organization) International Labour Standards On Occupational Safety and Health,https://www.ilo.org/global/standards/subjects-covered-by-international-labourstandards/occupational-safety-and-health/lang--en/index.htm

ILO (International Labor Organization) History of the ILO. http://www.ilo.org /inform/online-informationresources/research-guides/history/lang-en/index. htm, Erişim Tarihi: 13.11. 2018.

ILO Safety in numbers (2003) Selecting a low-safety, low-health and low-income survival strategy is not likely to lead to high competitiveness or sustainability.

Jewalikar, A. D., and Shelke, A. (2013).The main perceived benefits associated with hse management systems certification in msme tool rooms post quality management system certification' Journal Impact Factor, Vol. 4, No. 3:124-134.

Joo, B.K., and Lim, T. (2013).Transformational leadership and career satisfaction: The mediating role of psychological empowerment, Journal of Leadership and Organizational Studies, Vol. 20, No. 3:316-326. doi:/10.1177/1548051813484359.

Judge, T.A., Cable, D.M., Boudreau, J.W. and Bretz Jr., R.D.B. (1995). An empirical investigation of the predictors of executive career success, Personnel Psychology, Vol. 48: 485-519. doi:10.1111/j.17446570.1995.tb01767.x

Judge, T.A., Higgins, C.A., Thoresen, C.J., and Barrick, M.R. (1999). The big five personality traits, general mental ability, and career success across the life span, Personnel Psychology, Vol. 52: 621-651.

Korman, A.K., Wittig-Berman, U., and Lang, D. (1981).Career success and personal failure: Alienation in professionals and managers, Academy of Management Journal, Vol. 24, No. 2: 342-360. doi:10.2307/255846.

Kraimer, M.L., Seibert, S.E. and Liden, R.C. (1999). Psychological empowerment as a multidimensional construct: A test of construct validity, Educational and Psychological Measurement, Vol. 59, No. 4: 127142.

Kristof, A.L. (1996). Person-organization fit: An integrative review of its conceptualizations, measurement, and implications, Personnel Psychology, Vol. 49: 1-49.

Laszlo, A., and Krippner, S. (1998). Systems theories: their origins, foundations, and development, Advances in Psychology-Amsterdam, Vol. 126: 47-76.

Lofquist, L.H, and Dawis RV. (1991). Essentials of person-environment correspondence counseling. Minneapolis, MN: University of Minnesota Press.

Mearns, K., Hope, L., Ford, M., and Tetrick, L. (2010). Investment in workforce health: Exploring the implications for workforce safety climate and commitment, Accident Analysis and Prevention, Vol. 42, No. 5:1445-1454.

Menon, S. T. (2001). Employee empowerment: an integrative psychological approach, Applied Psychology, Vol. 50, No. 1: 153-180. 


\section{Ö. Turunç - İ. Akkoç - A. Çalışkan 12/3 (2020) 2864-2878}

Miller, P. and Haslam, C. (2009).Why employers spend money on employee health: Interviews with occupational health and safety professionals from British industry, Safety Science, Vol. 47, No. 2:163199. doi:10.1016/j.ssci.2008.04.001.

Montero, M. J., Araque, R. A., and Rey, J. M. (2009) Occupational health and safety in the framework of corporate social responsibility. Journal of Safety Science, 46, 1-20.

Nabi, G.R. (2001). The relationship between HRM, social support and subjective career success among men and women, International Journal of Manpower, Vol. 22, No. 5: 457-474.

Ng, T.W.H., Eby, L.T., Sorensen, K.L., and Feldma, D.C. (2005). Predictors of objective and subjective career success: a meta-analysis, Personnel Psychology, Vol 58, No. 2: 367-408.

Peluchette, J. (1993). Subjective career success: the influence of individual difference, family and organizational variables, Journal of Vocational Behavior, Vol. 43, No. 2: 198-208.

Poon, J. M. L. (2004). Career commitment and career success: moderating role of emotion perception, Career Development International, Vol. 9, No. 4: 374-390.

Quinn, R.E., and Spreitzer, G.M. (1997).The road to empowerment: Seven questions every leader should consider, Organizational Dynamics, Vol. 26, No. 2: 37-48.

Robbins, S. (2003) Essentials of Organizational Behavior. Seventh Edition, New Jersey: Prentice-Hall.

Seibert, S.E., Silver, S.R., and Randolph, W.A. (2004).Taking empowerment to the next level: A multiple-level model of empowerment, performance and satisfaction, Academy of Management Journal, Vol. 47, No. 3 : 332-349.

Sekaran, U. (1992) Research Methods for Business, Canada: John Wiley ve Sons, Inc.

Smallman, C., and John, G. (2001). British director's perspectives on the impact of health and safety on corporate performance, Safety Science, Vol. 38: 227-239.

Spreitzer, G.M. (1995a). An empirical test of a comprehensive model of intrapersonal empowerment in the workplace, American Journal of Community Psychology, Vol. 23, No. 5: 601-629. doi:10.1007/BF02506984.

Spreitzer, G.M. (1995b). Psychological empowerment in the workplace: Dimensions, measurement, and validation, Academy of management Journal, Vol. 38, No. 5: 1442-1465.

Spreitzer, G.M. (2007) Taking stock: a review of more than twenty years of research on empowerment at work, In C. Cooper, J. Barling, ed., Handbook of Organizational Behavior, Sage Publications.

Spreitzer, G.M. (2008) Taking Stock: A review of more than twenty years of research on empowerment at work. In C. Cooper and J. Barling (Eds.), Handbook of organizational behavior (pp. 54-73). Thousand Oaks, CA: Sage.

Spurk, D., Abele, A.E., and Volmer, J. (2011). The career satisfaction scale: longitudinal measurement invariance and latent growth analysis, Journal of Occupational and Organizational Psychology, Vol. 84: 315-326

Thomas, K.W., and Velthouse, B.A. (1990). Cognitive elements of empowerment: an "interpretive" model of intrinsic task motivation, Academy of Management Review Vol. 15, No. 4: 666-681.

Verquer ML, Beehr T.A., and Wagner SH. (2003). A meta-analysis of relations between personorganization fit and work attitudes, Journal of Vocational Behavior, Vol. 63: 473-489.

Warr: (1999) Well-being and the workplace. In D. Kahneman, E. Diener, and N. Schwarz (Eds.), Well-being: The foundations of hedonic psychology (pp. 392-412). New York: Russell Sage Foundation.

Wat, D., and Shaffer, M.A. (2005). Equity and relationship quality influences on organizational citizenship behaviors: The mediating role of trust in the supervisor and empowerment, Personnel Review, Vol. 34, No. 4: 406-422.

Yazıcıoğlu, Y. ve Erdoğan, S.(2004). SPSS Uygulamalı Bilimsel Araştırma Yöntemleri, Ankara: Detay Yayıncılık.

Zanko, M., and Dawson P. (2012). Occupational health and safety management in organizations: a review, International Journal of Management Reviews, Vol. 14: 328-344. 